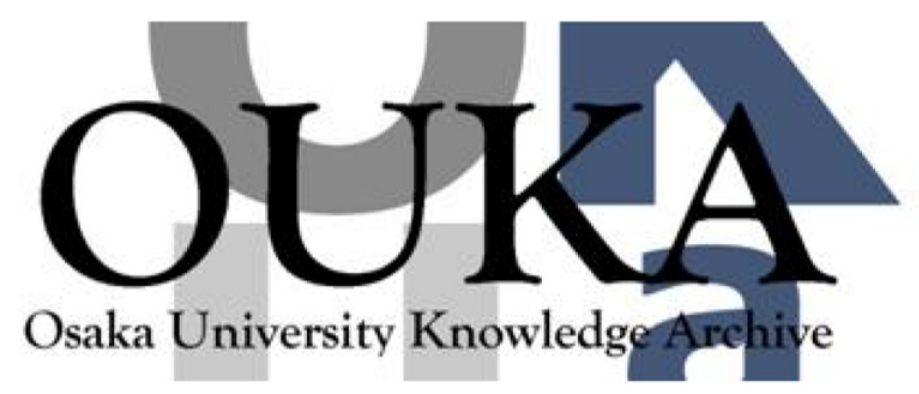

\begin{tabular}{|c|l|}
\hline Title & Educational Broadcasting in Japan \\
\hline Author(s) & 水越, 敏行 \\
\hline Citation & 大阪大学人間科学部紀要. 9 p. 189-p. 215 \\
\hline Issue Date & $1983-03$ \\
\hline oaire:version & VoR \\
\hline URL & https://doi.org/10.18910/10402 \\
\hline rights & \\
\hline Note & \\
\hline
\end{tabular}

Osaka University Knowledge Archive : OUKA

https://ir. Library. osaka-u. ac. jp/

Osaka University 


\section{EDUCATIONAL BROADCASTING IN JAPAN}

— ITS RETROSPECT AND PROSPECT

\section{Toshiyuki MIZUKOSHI}

\section{TABLE OF CONTENTS}

PART ONE : The History of Educational Broadcasting in Japan

Chapter 1: The First Term — The Era of Radio

Chapter 2: The Second Term — The Era of Television

Chapter 3: The Third Term — The Era of VTR

Chapter 4: The Fourth Term ‥ The Era of New Media

PART TWO: The Current Problems of School Broadcasting

Chapter 1: The Problems on Maker's Side

Chapter 2: The Problems on User's Side

PART THREE: The Subjects for Studies on School Broadcasting

Chapter 1: The Overview of Previous Studies

Chapter 2: The Future Studies on Broadcasting Education 


\section{EDUCATIONAL BROADCASTING IN JAPAN}

— ITS RETROSPECT AND PROSPECT

\section{Toshiyuki MIZUKOSHI}

\section{The History of Educational Broadcasting in Japan}

\section{The First Term - The Era of Radio}

The era of school broadcasting is divided into three parts. The first is the period of foundation. That is from the start of nationwide school broadcasting in April 1935 to the suspension in March 1945 owing to aggravation of World War II. It is the period of prewar school broadcasting. The second is the period of re-foundation that is from the re-opening in Oct. 1945. (it was only after two months from the end of war) -to the major revision of program contents in 1953. It is the period of early postwar school broadcasting. The third is the period of stability; that is the period until about 1961 in which the percentage of TV utilization (for school broadcasts) exceeded that of radio. Until then the utilization rate of radio broadcasting was about $50 \%$ in primary schools, about $40 \%$ in junior high schools, and about $30 \%$ in senior high schools. This is called the Radio Age.

In short, during the 50 years from the prewar period, radio broadcasting in Japan passed the three periods mentioned above and today the utilization percentage is keeping low, though the rate itself is exceeded by that of TV. The Fig. 1 shows the change of school broadcasting utilization rate after the war. (Akiyama, T. and Imaizumi, S. NHK Radio and Television Culture Research Institute 1981)

When considering the 20 years from the period of foundation to the period of stability only, there was not always a consistent concensus among the makers, the users, or the administrators. There were no less than two or three times of qualitative change during this short period.

A detailed explaination of the characteristics of each period is given below:-

\section{(1) The Period of Foundation}

All though this period the broadcasting programs obviously paralleled the school curriculum and the national text books. So, the Program Makers tried neither to overlap nor to cut short the content of text books. They took a form of extracurriculum. On the other hand, the maker, the user, and the administrator shared the consensus that radio was a unique, supplementary, teaching material which had the characteristics of instantaneousness, massiveness, uniformity, and still more, its depending on sound. 
According to "Educational Broadcasting in Japan" ... published in 1937 by NHK (Japan Broadcasting Corporation) - the maker's intentions of broadcasting are summarized as follows. (Akiyama, T. 1978) First, to supplement and enrich the school curriculum. Second, to have children learn how to use radio as a new promising medium (including developing their critical attitude). Third, to diffuse the standard language. Fourth, to diffuse and equalize the cultural opportunity to everyone throughout the country. For these objectives many programs were produced such as radio gymnastics, music education, lectures by eminent persons drama, and so on. They were mainly aiming at curriculum enrichment, as mentioned. Programs for teachers such as "Teachers' Hour" were produced to cultivate teachers' general culture. We do not know to what extent the audience of that time understood the maker's intention. But, guessing from the contents of programs mentioned above and the situation that radio gymnastics and the lectures by famous people were often utilized, we cannot help concluding that the practical state was far from the realization of these four objects, especially the second one. And we can also guess the maker's attitude to keep some distance from the national textbooks and at the same time to minimize the gap between their programs and national textbooks.

The characteristics of this period are summarized as follows : (a) In those days of broadcasting, characteristics of diffusibility and uniformity were valued as merits on account of very big gap both in culture and in education. The fact that the very first experimental school broadcasting in Tokyo in Sep. 1931 dealt with the model reading of text book guided by Toyotaro Tanaka, who was the teacher of the elementary school attached to Tokyo Teachers College at that time, shows it well. Now, when we overview the situation at world wide level, such tendency is often observed in developing nations and it makes a striking contrast to the developed nations' states such as Japan, USA, and EEC countries.

(b) Both the program makers and the users commonly regarded radio as a method of journalism education to train children to be good audience. This thought was succeeded in the following period of re-foundation. But, after the period of stability, it remarkably receded and the priority moved to the direct instruction of concepts and knowledges, and reinforcement of connection and fusion of Japanese school broadcasting with the units in the textbooks.

\section{(2) The Period of Re-foundation}

As mentioned before, it was only after two months from the end of the war that the school broadcasting was resumed. It was a big turning point for Japan, - from militarism to democracy. At that time education was in confusion and there were almost no printed matter including reference books or even textbooks. The communication network was in complete disarray due to war damage. Therefore radio was the most powerful massmedia available for its diffusibility, uniformity, and promptness. 
So NHK, school teachers, the Ministry of Education, and also CIE (Civil Information and Education) shared the idea that school programs should not get into the rut of the pre-war but be newly produced so as to match democratic education.

The testimony of Shoshin Aoki, (who was then engaged in school broadcasting at the Ministry of Education) that "We are resolved that we have made a refreshed start in cooperation for re-foundation of education" shows their firm determination. (Aoki, S. '78) (a) Then, on what points did the makers lay their stress ? According to Kozo Kawakami, who was the director of the NHK school broadcasting departmet during this period, they aimed at the following three points in developing new school programs which were different from the "supplementary and subordinate" pre-war ones. The first is to introduce new subject such as social studies and home science which became popular on account of the New Education Movement. The second is to produce teaching materials not for particular subjects, but for educating the new nation as a whole. The third is to signify "Teachers' Hour" to give teachers theory and practice in New Education Movement. Furthermore, Kawakami says, "There are delicate differences between school broadcasting and audiovisual education. School broadcasting must include the element 'new' and 'current' that is, there must be significant meaning for 'why' a certain program is broadcast on that time or on that day. Without this there no longer exists school broadcasting" (Kawakami, K. 1978) Such creeds as his were practicaly realized in many programs like "School Newspaper", "Travelling in Japan with a Microphone". and "Current Topics". It can be said that his creeds were the origins of today's school broadcasting and holds true even in present situation when VTR has became so popular.

According to Nobuo Terawaki, who succeeded Kawakami as the director of NHK school broadcasting department the following 6 points are indispensable on producing programs. (Terawaki, N. 1980) :

1. The program must contain something new in it.

2. The contents must be concrete so that the audience has a definite image.

3. The makers must signify emotional and sentimental phases.

4. The program must contain highly artistic elements.

5. The program should be accurate and fair.

6. The makers must produce such programs that make the best use of the function of broadcasting.

We can see "the spirit of educational journalism" in these sentences and the intentions to develop new possibilities and to breakdown old conventions by using this new communication medium, broadcasting. (b) Now, on the other hand, how did the teachers respond to these programs? Owing to the lack of radio sets, school broadcasting facilities, and nationwile organization of broadcasting researches for teachers, only a few pilot teachers were engaged in utilizing the new programs. There 
is an episode of a teacher who mounted his radio set on his bicycle every day, and used it in his classroom during the daytime, and then in the evening brought it back to his home. It was about 1949 that school broadcasting became pervasive in places in Japan with some enthusiastic teachers acting as the core - the teachers who distributed the guidebook for NHK's school broadcasting programs among colleagues - invited them to listen to some of the programs, and design the lesson plans so as to make use of school broadcasts. One such teacher was Satoshi Takachio. He used the school broadcast only as resource material and developed creative and unique lessons based on them ; that is, he signified the learning activities after listening to them more than the programs themselves. He believed that listening to school broadcasts was not supplementary of textbooks. It was a new learning activity which matched the "the spirit of educational journalism" already mentioned. And furthermore, his instructional strategies were the very practice of today's "learning through broadcasting" type of instructions.

The programs handed down to the educational broadcasting station amounted to 20 hours a week in 1953. Such kinds of programs as music, literature, current topics, and those intended for multiple grades continued to be broadcast. New programs which were presented for each subject and each grade appeared progressively. It was during this period that improvement both in quality and in quantity began to appear. And we cannot dismiss the fact that Japanese school broadcasting faced the big turning point, which was mentioned before, in this period.

Yasuo Takakuwa pays special attention to this kind of programs for each subject and for each grade, and points out that before the year of 1953 the school radio broadcast served to supplement and enrich the classroom activities. However, now it was no more supplementary but had direct teaching function. (Takakuwa, Y. 1978) In this way the idea that school broadcasts are supplementary teaching material or that it is the method of educational journalism, went away gradualy. The tendency next was to think that it should serve the function of direct instruction. This tendency was increasingly enforced with the appearance of TV. In sciences and social studies (which were used heavily) the stress was on the conformation, to the units of textbooks and on the picturization of the contents in them besides promoting the direct instruction role mentioned above.

However, it should also be noted that the appearance of such programs for each subject for each grade was due partly to the strong requests from teachers. As the program contents were enriched and the broadcasting hours prolonged, the chances for utilization also increased remarkably. Then it was only natural that the teachers demand close relation between the contents of programs and that of textbooks. In this way radio-textbook "fusion style" replaced the former "parallel type". Such demand became serious as the number of teachers who actively utilized the school 
broadcast increased. Another reason for this tendency was that the early postwar experimentation retreated where as systematic acquisition of the basic knowledge advanced. The 1958's revision of the Course of Study was very significant in the following two senses: first a certain legal status was attached to the Course of Study; second, it put forward the idea of systematic knowledge acquisition and of subject centered curriculum. Consequently the school broadcasts which were obliged to conform to the Course of Study, came to have such characteristics as correspondence to textbooks, direct instruction and to take that form for each subject and for each grade.

In short, it was about this time that the term "broadcasting subject matter" came into use and that the school broadcasting sacrificed its instantaneousness and headed for pushing forward "subject learning through broadcasting", thus signifying its more express function.

\section{The Second Term-The Era of Television}

1. It was in February 1953 that TV broadcasts for schools started. This was in keeping with the rapid economical reconstruction which took place following the period of postwar disturbance. The newly opened educational TV station (1959) specialised in broadcasting schools programs. So, the programs concerning education became completely separated from the general programs. It is remarkable that even in the limited hours available at the early stage of TV broadcasting, the makers incorporated school broadcasting programs into it. And, furthermore, 6 years after the beginning they made a new channel exclusively for broadcasting school programs. These show the enthusiasm of the maker in those days.

When TV broadcasting began (a survey reports) only 10 schools were provided with TV sets! Of these, 4 sets were offered free by NHK. As T. Akiyama says, the makers have been transmitting programs regardless of the poor utilization. This trend has been so even at the time of starting colour telecasting, sound multiple broadcasting, and other new devices. (Akiyama, T. 1980 a)

Even so, percentage of television broadcasts for schools rose up drastically. As Fig. 1 shows (especially 1-a, 1-b) more than 50\% of primary schools and kindergartens in Japan were using TV school broadcasts in 1960's. It was only a few years after the start of TV telecast that the utilization rate of TV exceeded that of radio. By the end of 1960's it had nearly achieved its current rates.

2. As the utilization rate of TV increased, that of radio decreased to a static low. This means that TV had not driven radio away. According to Tatsuya Ura, who is NHK chief producer of school broadcasts, with the appearance of new media, the old media come to limit their territory to where they are most skillful. Take the example of a social studies program "Travel in Japan with a Microphone". It dealt with the climate and the life of people in various places in Japan and it was a 


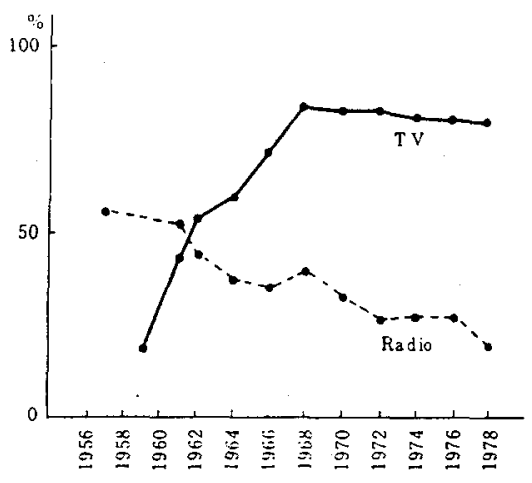

Fig. 1-a Kindergartens

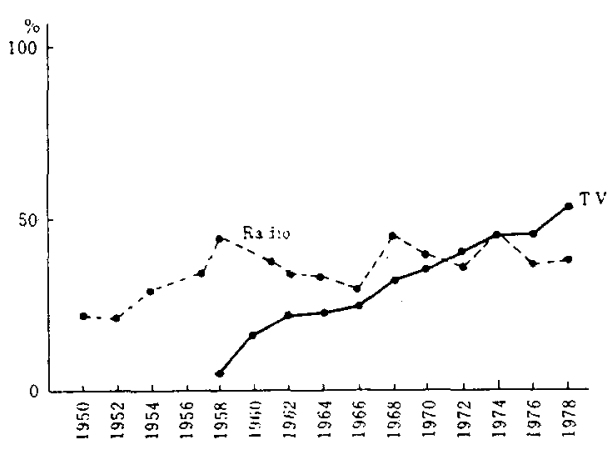

Fig. 1-c Junior High Schools

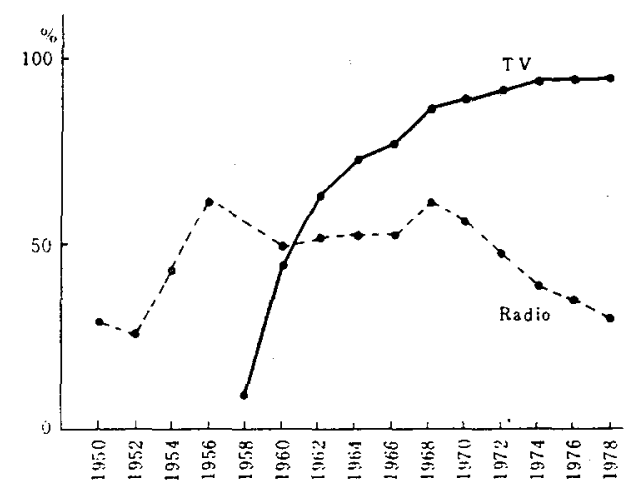

Fig. 1-b Primary Schools

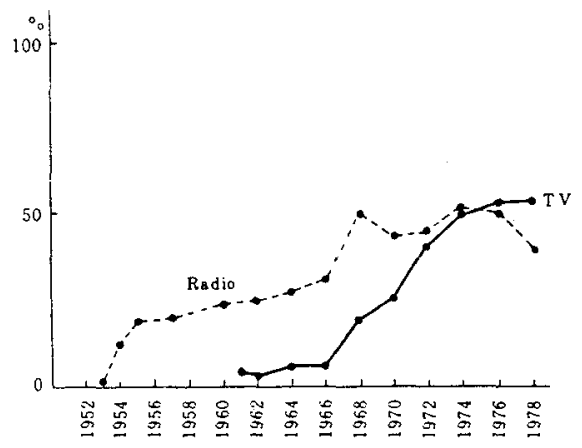

Fig. 1-d Senior High Schools

Fig. 1 Percentage of school broadcast utilization

life-long program. But it was obliged to give way to a similar kind of program in TV, "Travel in Japan with a TV Camera", because TV is more suitable for this kind of program. However, radio is still active in the fields where good characteristic of it can be brought into full usage, and it has attained coexistence with TV. For example, ln programs of literature and music which require imagination while listening, and in programs of moral education which can give children good models of behaviour, and so on. Ura's prediction that "Today's TV will follow the path of radio, in the coming new era of New Media" is worthy of our attention. (Ura, T. 1981)

\section{The Third Term The Era of VTR}

1. As Fig. 1 shows the TV utilization rate in primary schools and kindergartens had reached the present level by late 60 's. But on the other hand, in case of junior and senior high schools it was in 1970's that the TV broadcasting utilization rate reached 50\%. (Fig. 1-c, 1-d) There are two reasons for this. The first is that junior and senior high school courses are divided by subject matter rather than by year levels, 
the hours of school programs and the schools' class schedule did not always match. The second is the teachers' unwillingness to spare their time for utilizing the telecasts meant for schools because of their confidence or pride as professionals in each subject field, and of their familiarity to the lecture style instruction. But the diffusion of videotape recorders had helped solve these difficulties: that is, it enabled partial utilization of programs and playing back of them (even of old ones) at any time they wish. The excellent materials and resources in programs that teachers by no means can afford in classrooms attracted new group of junior and senior high school teachers.

As Fig. 2 shows, first high schools, and then junior high schools began to secure videotape recording equipment. This resulted in an increase in utilization of school broadcasts at these educational levels. The utilization rate in junior and senior high schools is still lower than that of primary schools or kindergartens. The primary school differs from the high school in the basic idea of utilization and its style. However, this problem (the difference referred to) has always been disputed at the meeting of All Japan Teachers Federation of Educational Broadcasting Research Association.

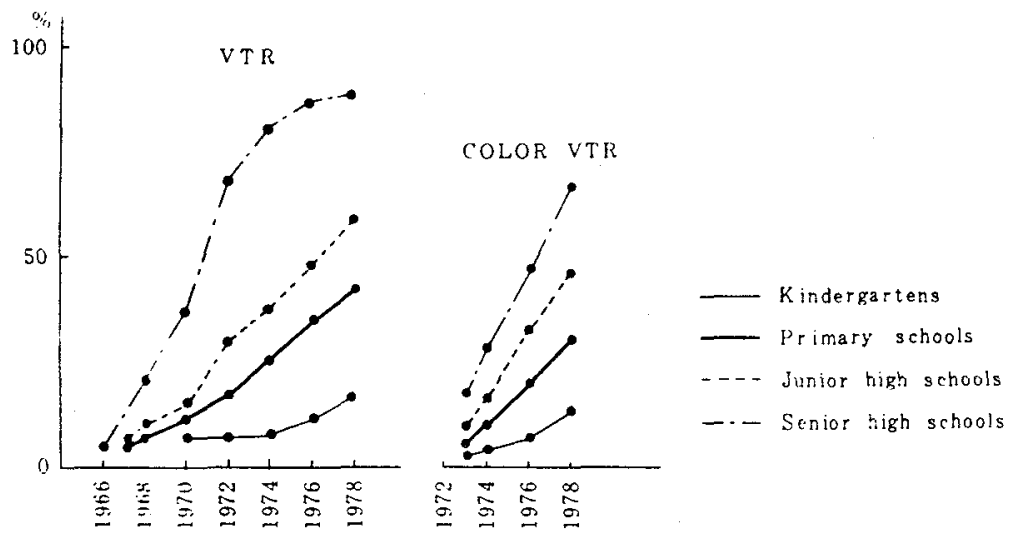

Fig. 2 Percentage of VTRs in use

2. The programs makers were using videotape recorded programs and transmitting them long before the diffusion of VTR among schools. And, then, schools began to use recorded and videotaped programs other than the "on-air" ones. This means that the programs are recorded and used twice over. If so, what is the meaning of live programs or live utilization? Furthermore, what is the difference between recorded programs and video package teaching materials? ...... We must consider this kind of problems deeply.

3. It is worth paying attention, that, not only was there rapid development of hard- 
ware, but, also, there were teacher organizations for utilizing school broadcasting which immensely contributed to the quick diffusion of it in Japan. (Mizukoshi, T. 1981) Nationwide meetings have been held every year attended by teachers from all kinds of schools, - (from kindergartens to senior high schools) - NHK's officers in charge of school broadcasting, scolars, and even parents and students, sometimes. Now, for these meetings more than 10,000 participants always gather. The high attendance suggests this field of study has gained popular support. The meetings have several objectives in view : to make effort to diffuse broadcasting-education; to exchange opinions on teaching strategies and utilization style; to introduce school broadcasting into classroom ; to supply feedback information to producers of programs by exchanging opinions between makers and users; so on and so forth. Before the 10th Annual Meeting was held in Fukuoka 1959, the main theme had been "Effective Utilization of Broadcasting"; but after that the theme of every meeting came to reflect the current educational thought. To name a few, - "Modernization of Learning Process" (the 15th Grand Meeting in Sappro), "Clarify the Structure of Learning Contents" (the 20th Grand Meeting in Sendai), "Introduction of Systematic Way of Learning" (the 22nd Grand Meeting in Kanazawa) ...... were some of the themes.

This change of theme shows that the development of school broadcasting was not independent of that of education; and that the change mentioned above never happened by itself.

4. In 70's the school programs were rapidly diversified. Traffic safety, environmental education, and other new programs have become a part of school broadcasting. In addition, the general and cultural programming - recorded by teachers at home or at school-teachers' own programs, and other formats have been brought into the classrooms to be used alongside the school broadcasts. Boards of Education in various prefectures have become sponsors of prefecture-wide school broadcasting on either FM radio or UHF television. Many of these were initiated between 1970 and 1972. Some of the commercial broadcasting stations also produced several school programs. For example, MBS social studies programs for grade 4 in the Kinki district. NHK covers nationwide network. Therefore, is difficult for them to produce local programs; or, to fully reflect the request of local teachers in them and teachers guide books. The Education Boards of each prefecture and commercial stations followed up this (NHK's) weak point and aimed at "school broadcasting closely related to locality". However, this meant that the programs became "textbook/reader conformation" style or "video package" style, and it will lead to the problem "What is broadcasting?". On the other hand, from the mid-1970's simultaneous or parallel viewing by parents and children has been promoted. Experiments in having both parents and children view either school or general programs at school or at home have been successfully undertaken in a number of localities. 
Activities involving use of TV in adult education, particularly for housewives and elderly groups, have also become predominant. Normally, these groups watch at home programs which have been agreed upon earlier. Once or twice a month, they gather. together for discussion; and then, for viewing the programs for the second time.

In this way, the contents, the users, how and where they use, all changed! Here, a change of concept of educational broadcasting from "school broadcasting" to literally, "educational broadcasting" in its broad sense may be recognized.

\section{The Fourth Term The Era of New Media}

It is New Media that accelerated the varying tendencies furthermore. According to T. Ura, "the period when TV functioned as the projector of electric wave through air has ended". And now, TV is included in the larger communication system which is shown below: (Fig. 3 Ura, T. 1981). In other words, for quite a long time the TV set could not project anything other than the electric wave sent out from the broadcasting stations. But, now the New Media (free from the use of antenna as VTR; and two way communication system in a certain area wired with cable) has broadened the usage of the TV set.

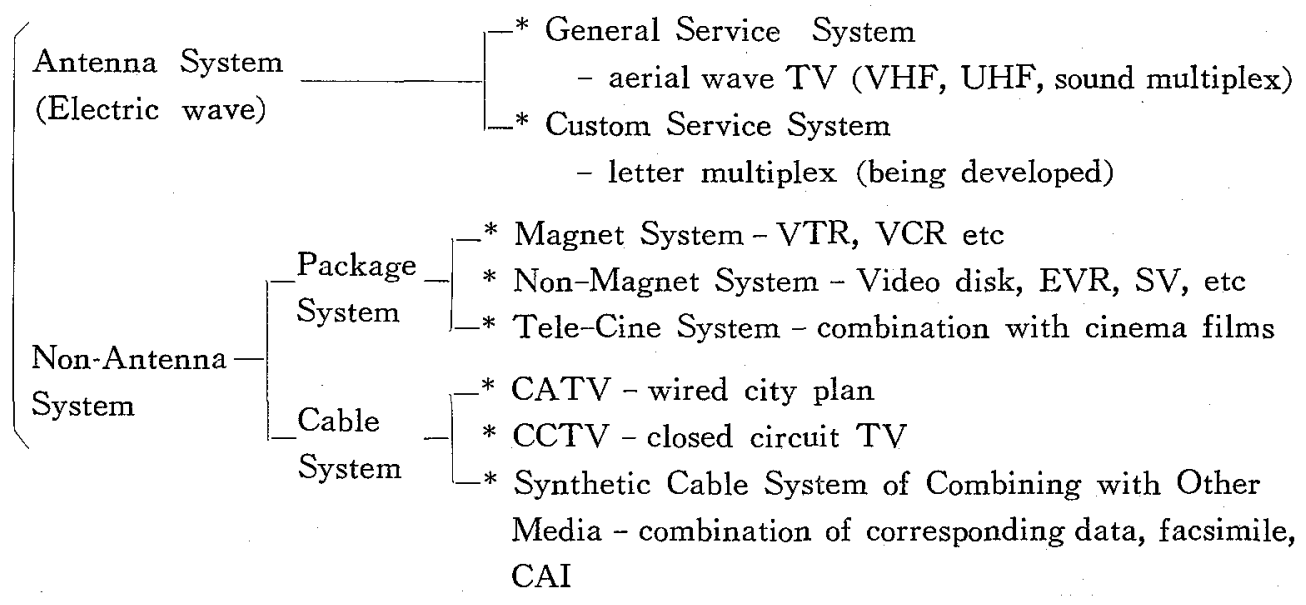

Figure 3: Communication System Using TV as End-terminal

Under such a situation, it is unavoidable for TV to hand over some area where TV has its weak points to the New Media. That is, the users are able to repeatedly utilize their favourite programs at any time they like by using VP (video package), and enjoy two way communication by CATV (cable TV) and CCTV (closed circuit TV), or CAI (computer assisted instruction). The Ura's hypothesis that TV would attempt to coexist with such new media fully exhibiting its good characteristics in a purified way will surely be accomplished. When such time comes, where should we 
classify TV school broadcasting? - in antenna system or in non-antenna system?

NHK committee, which consider NHK role for longer vision, revealed their positive attitude to attempt to coexist with new media. (NHK 1982). According to this report, they are now planning to launch a broadcasting satelite in February 1984, whereby still picture broadcasting, Hi-Fidility broadcasting, and High-Definition TV would be put into practical use in 1990's. Then some of the functions which former broadcasting lacked, that is the selectivity of programs and opportunities, the recording function etc. will be supplemented by them. Furthermore, they would enable to provide better services for specialist and minority people.

Any way, the appearance of new media have fundamentally changed the outstanding characteristics of school broadcasting : this is any one in the long archipelago of Japan is exposed to the very same program at the same time. The problem would be that to what extent the broadcasting is able to respond to the various needs both from teachers and students. School broadcasting would necessarily face the task to fulfill the two functions of education : to promote individualization for each child and at the same time to accomplish the common goal for all. The technological conditions necessary for such a project has already been set.

\section{The Current Problems of School Broadeasting.}

The process of diffusion and development of school broadcasting in Japan has been so rapid as to leave little room for comparison. Many new situations such as the following have appeared in a very short period.

1. As the number of teachers and students utilizing school broadcasting increases, their needs and abilities are greatly diversified.

2. Programs themselves have become too varied to be classified in one category of school broadcasting. As an example, think of the difference between a social studies programs taking a news or documentary format and a mathematics programs which may use animation.

3. The utilization style has also changed with the appearance of VTR and ATR. These tendencies will be more pronounced with the appearance of new media. Many new phenomena have appeared in rapid succession. Because of these changes, many new problems and difficulties have appeared and they await solution. The discussion which follows would concentrate more on TV than on radio.

1. The Problems on Maker's Side.

1) Capabilities of broadcasting are not utilized fully yet - Almost all school broadcasting programs are pre-recorded. Some of them are even re-broadcast from the previous year. (particularly in the case of science programs). Even if the children view the program 'on-air', the program itself is not live and the 
'instantaneousness' of broadcasting (which is one of its advantages), is being ignored completely.

2) Broadcasting is being used as an 'amplifier' to increase comprehension of students - The cognitive aspects are strongly emphasized. Most programs are designed with the viewer's opinions and understandings reflected in the producer's thoughts. Programs makers lay their stress on the function of expression which is to promote viewer's better understanding of concepts and principles and/or to help them learn the methods of inquiry and the procedure of manipulation (This is particularly true for science and mathematics programs).

At the same time the affective aspects-emotions, empathy, sympathy, etc.-are seen as secondary. Today, we have only a few programs which depend upon the images they present and result in both diffused thinking and diverse interpretations.

3) Programs emphasize oral explanations which never refer to the images being presented. - The TV programs are centered around a digital symbol system, the iconic elements are given only secondary position at best. This is a common problem in many countries. Dietzeid pointed out that "TV has been used as a method of conveying linguistic message regardless of iconic message. Consequently, the old type of educational practices, for example, emphasis on learning by memo rizing, encouragement of passive attitude toward learning, and idealization of TV teachers have been enforced." (Dieutzeid, 1970)

\section{The Problems on User's Side.}

1) The researches of school broadcasting remain only a kind of educational movement with little direction being given towards deepening and generalizing its results. Now every year there are both regional and prefectural level conferences on school broadcasting and audio-visual education. Such conferences have produced considerable outcomes. There seems, however, to be several unfavourable points with respect to the quality of the outcomes. First, transfering the results and the methods of research from one sponsoring region to the next (for use the following year) happens only seldom. Consequently, the new host region or school is forced to start their research from even the smallest kinds of preparation. Secondly, researches based on continual observation or survey are very limited. No generalization from the experiences of the specific classroom instruction is sought. In short, these meetings are effective as a means for diffusing the use of school broadcasting but scarcely result in the deepening of quality of researches.

2) There are only exchanges of slogans and ideologies instead of pursuits of substantial essence of school broadcasting research. For example, even though the purpose is to develop the audio-visual literacy and the ability of information processing, the factors and structures which formulate these abilities and their 
relationships with intellectual abilities, etc; are not clarified. In addition, there is little research on difference of patterns of children's information processing and what types of camera work and auditory effects influence the viewer's understanding of the main theme or catching the key scenes of the program. At meetings held nowadays, slogans such as' Developing Creativity' or' Cultivation of Humanity' with no basic or fundamental researches to support them, are being uttered. Furthermore, there are tendencies that the utilization styles such as 'live-program full time utilization' or 'continuous series utilization' do exist. The factors which contents of the programs and the actual condition of the children are also should not be ignored.

3) Dominance of Dualism. - The purposes and methods for using broadcasts are divided into either 'TV-text book in parallel' versus ' $T V$-text book in combination' or into 'direct teaching' versus 'curriculum enrichment' To put the problems in this dualism naturally demand selection of one side of view and the exclusion of the other. This trend has not disappeared even today.

As mentioned, we are now in the era of New Media, ushered in by the progress of hardware. The software (for e. g. programs) have advanced to catch up with it! Nevertheless, the theory and practice of the use of school broadcasting, especially in primary schools have not changed much since 1950's. Today, VTR has become popular in the schools, programs are diversified and specialized, the needs and abilities of teachers and children are also varied, and new media such as video disk, two way communication cable TV, electrically edited newspaper etc ; are intruding into the classrooms. Under such circumstances, what we must do is clarify the possibility and limits of broadcasting through practices considering the objectives programs content, children's condition, and their collective effects. The theory and practice of school broadcasting can hardly keep up with the rapid development in hardware and the change of software without the said conception and approach.

4) Generalization of the teaching-learning strategies and lack of teachers capable of using educational broadcasts. Japanese teachers (from kindergartens to senior high schools) are all licenced personnel. The majority of them are taught the subjects necessary for the teaching profession. Even after they have entered the teaching profession they are periodically given in-service training on new curriculum, instructional methods, teaching instrumemts, and so forth. Nevertheless, such teacher training strictly follow the conventional pattern; a teacher and students sit face to face, using the form of questions and answers, laying stress on print media, such as the text books.

On the other hand, school broadcasting aims at making the lessons given by the TV teacher, effective. It does not rely on TV teacher completely: co-operation with classroom teacher is hoped for. It requires, however, advanced teaching techniques to 
realize this. At present, a few enthusiastic teachers possess these techniques which are not yet the property of all.

Owing to the reasons mentioned above, the rest of the teachers have no chance to be informed about the said strategies and there is no way other than start from zero and accumulate their own personal experiences through trial and error. This also explains one possible reason as to why teachers tend to choose one out of the two opposing types of utilization.

The diffusion of VTR, it has been repeatedly emphasized, has brought about the specialization and diversification of the content of programs utilization styles, and objectives. For example, in one case, junior high school teachers use English programs in the form of direct teaching and parallel use; in another teachers use Moral Education programs for lower grade pupils in primary schools (expecting modeling effects) and afterwards have them play the roles in them, some others use Science programs for senior high students making good use of materials which teachers cannot afford in classrooms and follow up by using multiple media as OHP, slides, response analyzers the real objects, the models, the text books etc; still others use animation drama for kindergarten children, counting on the motivation effect and develop it to various activities such as singing, drawing, and houseplaying. The teaching strategies and tactics suitable for each stage of each case must vary from one to another. They are now under study and are being developed through practical experiences. However, it is keenly expected to distinguish between methods which are particularly suitable for a certain teacher and a class and methods which can be the generalized for all.

\section{The Subjects for Studies on School Broadcasting}

\section{The Overview of Previous Studies}

Let's look at the previous studies on school broadcastiog. T. Akiyama has described the following four types of studies among many others from the view point of "Studies on Educational Effectiveness of the Pictures". (Akiyama, T. 1980,b). The comments given below are based upon his studies.

\section{(1) Comparative Studies Between Use and Non-use of School Broadcasting}

This type of study happens to be the most familiar. The orthodox way of study is to focus on the differences of response, effectiveness and its duration between two groups; one, experimental; the other, control. For example, one group has received abundant experiences of TV and/or film viewing; and the other has not. During the study, both groups view the same film or TV program and the researchers look for any observable differences. In course of time, much complicated comparative 
studies appeared. For example, conditions such as the contents of film (impressive or cognitive), subjects characters (sex, developmental stage), and input format (only film, plus instruction, no film) were altered. Recently, TV programs or VTR films replaced the educational films, and there is no one in Japan was has never viewed TV or movie. So, the researchers began to compare in different ways. For instance, comparison between the long-time viewing group and the short-time viewing group, or between school broadcasting utilizing group and not utilizing group.

(2) Analyzing the Different Effects of Different Media

These studies do investigate the effect brought about in learning, a certain concept, or a thing by usiug various media, such as the moving picture of cinema or TV; as still picture of OHP or slide projector; and printed materials. Such studies have also been conducted from the early stage. However, as Akiyama explicate, "the studies which handle not only the effectiveness of a single medium but also that of a combination of multiple media are needed. Requests from the teacher and the types of children should also be taken into consideration". Because, in the near future, instruction using various media will be realized.

(3) Analyzing Pictures by the Semantic Differential method (SD Method)

These researches were carried out by the NHK Radio and TV Culture Research Institute around 1960, for some time. University laboratories and schools also conducted this kind of research in the fields of social studies, sciences, and moral education. These researches analyze the contents of the programs or films by means of measuring the children's affection toward each scene. The children (viewers) respond from "interesting to boring" or "favourable to unfavourable". But the information obtained from this kind of response analysis device is very limited. So, a new method of research has been introduced to supplement it. That is to have children (viewers) write a short essay or have them set meaningful paragraphs. This became popular from the around 1970. These methods provide feed back information about the program to the progrm makers. If we consider the outcome from this kind of research in association with the degree of children's ability to understand contents or respond effectively, we will be on our way to research on individual differences in school broadcasting.

\section{(4) Analyzing the Teaching Strategies for Learning through Broadcasts}

This kind of researches are to analyze the interaction and the level of program understanding when there is or is not either pre-viewing or post-viewing guidance by the classroom teacher. Consequently, they revealed that the degree of programme understanding is promoted when there is pre-viewing or post-viewing guidance. The school teachers, especially primary school teachers, are more absorbed in this kind of studies. They have been conducting many kinds of research on utilization styles: parallel-continual viewing, fusing-continual viewing, etc., which are popular in class- 
rooms.

\section{(5) Other Techniques}

Another researcher, T. Tada made an experimental programs for social studies named "Fishery of Seto Inland Sea", in which the iconic techniques and the picture montages were taken care of. He had children-from the 3rd grade of primary school to the 2nd grade of junior high school-view the program and researched on cognition of picture montages, degree of understanding of the picture context, and the impression of the program. (Tada, T. 1966) Another study of his is that using the experimental program for science named "The Change of Strata". He made two different types of programs for this unit : one was in ordinary setting; and in the other appear many words and gestures which promote children's imagination. Consequently, the difference of the degree of imagination and understanding between these two types of programs were manifested. (Tada, T. 1980)

A team of researchers at the University of Kanazawa conducted a somewhat different experiment. They had children-from the 4th grade to the 6th grade of primary schools-view the social studies programes and administered various kinds of questionnaire, achievement tests, etc. at each stage (pre-viewing, on the spot viewing, and post viewing). Not only the children but also the teachers, parents, and principals of their schools did answer these questionaires. The programme proved to be effective with some classes or schools but not with others. Human relations in the classes and learning strategies that were not directly related to broadcasting, caused these differences. (Mizukoshi, T. et al. 1972)

These researches were not necessarily dealing with the effectiveness of films and pictures. However, they were very important in that they suggest some implications on the relationship between the children's audio-visual literacy and their montage techniques by means of producing experimental programs introducing various kinds of camera techniques. The research described last of all, probes into the basis for introducing education using broadcasting and was found to give good results.

\section{The Future Studies on Broadcasting Education}

It is next to impossible to fortell what kind of researches and studies will become necessary in the field of school broadcasting, which can have a flexible future. So, at best, only a guess can be made as regards the possibilities and necessities of future studies which can certainly be derived from the current practices. (Mizukoshi, T. 1982)

(1) Basic Studies on Communication and Teacting-Learning Process using AudioVisual Materials

The studies on human memory and information processing mechanism made a 
rapid progress in the last ten years. Interdisciplinary study fields such as "cognitive sciences" are now established. The studies on school broadcasting attempt a reconstruction of their study fields and methodology by absorbing not only the customary ideas of educational psychology, education, or communication theory but also new ideas of new fields which have grown rapidly. It has become necessary to re-explain the universal truth about the following points.

(A) Different persons are interested in different parts, impressed differently and evaluate in different ways even if they view the very same film or program. We should pursue this in relation with "cognitive map" and "learning set" of each person. (B) Why is the picturized information more understandable and more effective in motivating the audience and helping them to imagine the contents compared with literal or numeral infomation? Sceiford supposes that studies on the effectiveness of colour; motion; and learning process; plus that of audienceinterest, should be conducted. (Sceiford, 1978)

(C) Various cues are given in the TV programs (For e. g. zoom, close-up, repetition, slow-motion, rapid play back, etc.). Other activities which occur may include audience participation (not only during the performance, but during the discussion following the program; further studies; and correspondence with the producers etc.). How can these contribute towards learning through TV? Sceiford believes that the resuling situation will help learning.

(D) The children are said to develop ecological points of view by continual viewing of annual series program called "Green Earth". But on other hand, it consequently forms a stereo type learning set in them. Vester insists that it results from the "accustomed passage for information processing" in brains. (Vester, 1975) Why does such a thing as that happen?

(E) It is often said that lessons which use audio-visual materials should be evaluated by means of audio-visual method. Why should there be a great debate in trying to sort out problems as regards the method used for instruction and that used for evaluation? Schramm insists that we, humans do process digital information mainly in left part of our brain and iconic information in right part, and says cynically that the conventional instructions have contributed to develop only the left part of brain. According to this theory, post tests using linguistic questionnaires for audio-visual instruction are meaningless, because the children are forced to process information in left part of brain at the time of post test, even though audio-visual materials stimulate the right part of brain. (Schramm, 1977) It is questionable if the studies mentioned before considered this point: that is, the fact that instruction method and evaluation method must match each other in the sense of code used. In the latter half of this chapter, the methodology of audio-visual evaluation will be discussed in detail.

(F) Nowadays, various kinds of instructional methods for "pre", "on the spot", and 
"post" are introduced for audio-visual education. Eor example, suggesting the contents, enumerating knowledge already learned, and giving some viewpoints before viewing programs would constitute "pre-instructions" (functioning as advance orginizers). Again, writing freely any points and expressions while viewing program would constitute "on-the-spot instructions". Discussing impressive parts in groups and writing them on small cards, then grouping them according to the contents of programs would constitute "post-instructions".

Now, we must pursue the effectiveness of these strategies in the light of human information processing mechanism.

(2) Studies on Audio-Visual Literacy and Individual Differences

No one would deny the importance of audio-visual literacy. However, we hardly know its elements compared to those known about intelligence and creativity. So, looking at some preceding studies may be very useful.

Allen enumerated intellectual abilities necessary for audio-visual learning. They are ability of abstract reasoning, paying attention, percepting function, coding the percepted things, and analyzing. (Allen, 1975)

Salomon supposed six basic skills necessary for audio-visual learning and developed an evaluating method for them. The skills are: visual memory, grasping relationship of parts to the whole, fill up the blank parts of a story, etc. (Saloman and Cohen, 1977) Taking these preceding studies into consideration the following subordinate elements of audio-visual literacy can be suggested; and evaluating techniques for each of them developed. (Mizukoshi, T. 1981)

A. recognition of pictures

B. recollection of picture sequence

C. time concerning recognition (distinguish the past and the present) and spatial recognition (grasping the relationship of parts to the whole)

D. division of film paragraphs

E. grasping of important scenes

F. grasping the theme of the program essentially bound together

G. foretelling the story

H. reconstruction of the program (arranging pictures in the correct order, excluding and inserting certain parts)

I. generalization (forming general concept through joining some scenes and programs)

J. imagination

K. affctive response (impressions about the programs and sympathy with the characters appearing in the programs.)

The imagination $(\mathrm{J})$ is equivalent to "mental picture imagery" according to T. Tada. (T. Tada, 1980) This is inbetween the cognitive area and the affective area, so it can be expected play the part of connecting both areas. S. Yoshizaki statistically 
showed that the cognitive area and the affective area are vividly separated with inbetween by the empirical study on "Green Earth" for higher grades of primary pupils. (Yoshizaki, S. 1981)

Now let's go into the individual differences of audio-visual literacy. When we refer to the individual differences, we must explicate not only the simple and measurable differences such as speed or degree of achievement but also more complicated differences, as that of degree of understanding, viewpoints, sensation, and way of thinkig. The Rorschach Test and Thermatic Apperception Test (TAT) have been used to project the complicated individual differences, but "it is only natural that the individual differences in the true meaning are actualized most clearly when one looks at the pictures which present more complicated and latent meaning in them than the blots of ink or a single picture". (Ogi, M. 1979) To say the least, in moving pictures such as TV, the differences in understanding and the way of thinking will be more and more diversified. We must try to push forward this kind of psychoanalytic way of study on individual differences focusing on the points mentioned above.

The 11 elements-(A) to $(K)$-already being tried out during evaluation of audiovisual literacy, are divided into three areas: cognitive area ... $\mathrm{C}$ (from basic skills to that of high levels), image area ... I, and affective area ... A. Investigating the individual differences in the three areas referred to will be a corner stone in the sphere of research in audio-visual literacy. For instance, the team of researchers at the University of Osaka produced two animation programs and one documentary program and conducted a survey in which 1811 students of primary schools and junior high schools participated. 110 of them constituted the higher rank $\left(\mathrm{M}+\frac{1}{2} \mathrm{SD}\right)$ in all three areas ( $\stackrel{+}{\mathrm{CI}} \dot{\mathrm{A}}$ type). 74 of them constituted the lower rank $(\mathrm{M}-1 / 2 \mathrm{SD})$ in all three areas ( $\overline{\mathrm{C}} \overline{\mathrm{I}} \overline{\mathrm{A}}$ type). We have recognized 25 different types between the two. (Mizukoshi, T. 1982) Furthermore, search for the relationship between effectiveness and intelligence, creativity, school grades performance, etc., should reveal the individual profit which is most important for school education and also is difficult to evaluate only in classroom.

\section{(3) The Development of Evaluation Method Using Pictures}

As we have already seen, it is often the case with present audio-visual education to use tests relying upon written language to evaluate the results even though various kinds of iconic codes are introduced in classrooms. And many incorrect conclusions are made alike: "there was neither significant nor meaningful difference between audiovisual group and non-audio-visual group" is one of them. The criticism that such experiments are illogical has been raised by many scholars from early times.

Schramm, for example, conducted comparative study between audio-visual group and non-audio-visual group in El Salvador for five years. According to the general ability 
tests administered both at the beginning and at the end of the learning, the audiovisual group performed far better than the non-audio-visual group in non-linguistic area of tests, while in cognitive area there scarcely was seen any difference between the two groups. This shows that audio-visual learning group had acquired not only the cognitive way of information processing but also the iconic way of doing so.

Schramm insists that if it had not been for the fact that general ability tests included "non-linguistic area", such effectiveness could not be officially approved. (Schramm, 1977) Szabo and his co-operators have described evaluation by means of audio-ivsual techniques by using a unique phrase: "the second dimension of audio-visual literacy". (The first dimension is the practical utilization of audio-visual media in calssrooms; and it has become popular. Then, an introduction of audio-visual way of evaluation was needed which will enable us to measure efficiently the new qualities of information processing ability attained through lessons using various kinds of aud io-visual media ......) He concluded from his practical study that the senior high students who used audio-visual materials obtained the best results in all four kinds of tests on the basic knowledge, for e. $g$. in the rate of words fixation; the understanding about the function of heart; etc. (Szabo et al. 1981)

These experiments were comparatively primitive ones. We have been engaged in evaluating audio-visual literacy by means of audio-visual methods as follows: we made monochrome photographs from a TV program and used them as the post tests.

With these tests we investigated audio-visual literacy from lower to higher levels: that is, A ... picture recognition, B ... arranging picture according to the correct order, H ... re-constructing the program contents, I ... generalization, etc. (Mizukoshi, T. 1981)

In the other study using animation, we stopped the program halfway in order to have the children forecast the story which was to follow and to make it up using three illustrations out of 12 available. (Mizukoshi, $1982 \mathrm{~b}$ )

From now on, more detailed researches are needed. We cannot evaluate all elements of audio-visual literacy with only one program or method. So, it is necessary to develop adequate programs for evaluating each subordinate element of audiovisual literacy such as fluency of image, originality, affective responses, understanding of the theme foretelling the story, and setting meaningful picture segments. Each one of them should be developed separately and be tested for its effectiveness and validity as a evaluating method. Besides, the supplementary experiments of Salomon's may be needed; that is, analyzing the interaction between children's aptitudes and audiovisual literacy by means of changing camera works and montage techniques.

(4) The Study of Typology of Teaching-Learning Strategies in Educational Broadcasting

It has been repeatedly mentioned, that school broadcasts have been diversified 
and specialized; and that there cannot be an uniform way or objective even in similar schools. They naturally and qualitatively differ from school to school or from class to class. Nevertheless, the teaching and learning strategies are not systematically established yet. The following discussion can be useful in developing a typology for studies in the future.

\section{(A) The Direct Instruction Type}

Subjects such as Japanese language, English, Mathematics, special series programs; and general programs such as analysis of current news, belong to this type. The main object of viewing such progams is to develop the ability of grasping the purpose and to understand the important points of programs which are broadcast only once. (even if the materials are video tape recorded, here, the children view them for the first time and only once). In this type of utilization, teachers aim at a kind of "journalism education" which is different from the units of the textbooks. A readiness, preparation, and arranging of knowledge already attained, are needed before they view the program. And afterwards, conducting of Question and Answers (hand made by teachers) ; supplementary explanation of the contents ; and recommendation of reference books, are necessary. Furthermore, the importance of instracting about "information processing" must be stressed. Teachers simultaneous viewing is very necessary for this method.

(B) The Amplifier of Understanding Type

The program on social studies and sciences belong to this type. These have plenty of data and may be utilized in recorded style. In this type of utilization, broadcasting is regarded as one of multiple media used in classrooms. Children learn the contents of program when used in combination with textbooks through generalizing and imaging the abstract concepts. Teachers should carefully design the lessons so, that these multiple media function as a whole in arriving effectively at the objectives. In order to attain this, they must view the programs beforehand and consider the interaction with the other media.

(C) Aiming Further Study Type

These are the programs for environmental education and special series programs for Japanese literature and sciences. The children attain the motivation of inquiry and learn how to invesigate and how to summarize through viewing these programs. So, teachers lay stress on instruction after viewing. They try to set learning activities which encourage inquiry or divert thinking; and they give helpful advice in planning and conducting investigation and experiment ; or in performing productive activities.

(D) Modelling Type

Moral education, special educational activities, and other general programs such as "Diary of Junior High Students" belong to this typs. This kind of program is 
utilized as a method of giving children "the most desirable model". Children reflect themselves as the characters in the programs, sympathize, and virtually put themselves not in the outside but in the inside of the programs. Teachers propose some subjects before viewing. And then after viewing they instruct the children in such a way as to accept the problems in the program.

(E) Original Type

This type differs from the others in nature. Children experience both "producer" and "audience" at the same time by means of producing, broadcasting, viewing, and evaluating their original programs. This type has not received the regard it deserves. There is proof of marvelous effects not only in affective domain (motivation; and satisfaction brought about by accomplishing the task), but also in cognitive domain (deeply understand and exactly grasp the contents). Furthermore, we can expect a lot in developing basic audio-visual literacy. Children are given the liberal chance of experiencing "cameraman", "producer", or "supervisor" through this activity of producing their original programs. They suddenly know that there are many intentions of producers or cameramen in the programs and realize the differences in the way they see the outside world. It is through these creative activities that they can truly learn the relevant techniques. It goes without saying that these precious experiences surely contribute to their development of audio-visual literacy.

The utilization styles mentioned above are just some illustrations. So, a program for social studies can be utilized in any style, not only in style B but also in A, D, and sometimes in C. The most important ability of teachers is the decision making on "objectives". Decisions concerning the age of children, the kind of program and the manner of using them must come from the teachers using broacasts. Also, the way of evaluating the results remains their responsibility.

Moreover, the "development of curriculum for cultivating audio-visual literacy" which enable the combined practice of the five types mentioned above must be pursued at school, or preferably, at regional level. However, at this stage, it is premature to expect a particular teacher to do so in a particular classroom. Such a state as "development of curriculum for cultivating audio-visual literacy" cannot be realized simply because the particular teacher is very enthusiastic. A combined practice must be pursued further in order to realize any considerable result.

I wish to thank Mr. Tunga de Alwis (Curriculum Development Centre, Sri Lanka) for helping me in translating and editing. 


\section{REFERENCES}

秋山隆志郎（1978）全国むけ学校放送の開始, 教育と放送范考元る会編, 故送教育の新展開一一学校教育 に奶ける故送利用の総合的研究——（日本故送教育協会） p. 29.

秋山隆志郎 $(1980, a)$ 故送教育の歴史と現状，大阪大学人間科学部での請演速記録より

秋山隆志郎 $(1980, b)$ 映像の教育効果に関する研究, “映像と教育”研究集団編, 映像と教育一一映像の 教育的效果とその利用——(日本故送教育協会) p. 91 128.

Akiyama, T. and Imaizumi, S. (1981) School Broadcasting in Japan (NHK Radio and Television Culture Research Institute)

Allen. W. H. (1975) Intelectual abilities and instructional media design. AV Communication Review, 23 (2) pp. 139-170.

青木草心（1978）昭和20年代の学校放送〜文部省の立場から〜教育と放送を考える会編，放送教育証 言 集，未公刊(てれは筆者もその一人であった “教育と放送を考无る会”のメンバーが，戦後初期の放 送教育に中心的役割りを果たした人から証言をとった記録である。以下同じ）

Dieuzeide, H. (1976) Educational technology and development of education. Phillips J. Sleeman and D. M. Rockwell (ed.) Institutional Media and Technology. (Dowden, Hutchinson \& Ross). pp. 15-32.

板谷駿一（1982）テレビ報道の世界，NHK 総合放送交化研究所編，テレビ・ジャーナリズムの世界 現場からの発想——(NHK ブックス, 日本故送出版協会) p. 18〜21.

川上行蔵（1978）昭和 20 年代の学校放送 〜送り手の立場から〜 教育と故送を考元る会編，放送教育証 言集

水越敏行・小嶋秀夫・富安芳和 (1972) テレビと授業の効果 ——金沢調査の報告一一明治図書

Mizukoshi T. (1981) Educational broadcastingin Japan. School Psychology International. 2 (1), pp. 3-7.

水越钽行 $(1982$, a) 1982年・視聴覚教育，36（3）(日本視聴覚教育協会）をもとにして加筆した

水越敏行 (1981) 編, 視聴能力の形成と評価——新しい学力づくりへの提言—— (日本放送教育協会)

水越敏行 $(1982, b)$ 視㯖能力の個人差とその評佂，炤和 $55 ， 56$ 年度科研研究成果報告書 個人差の評価 の指導得する関す実証的研究 p. $61 \sim 75$.

NHK (1982) NHK 長期ビション審議会調查報告書 (NHK 視聴者本部広報空)

荻 昌朗（1979）映像情報のドキュメンテーション NHK 放送交化研究所編，放送学研究，13号 p. $27 \sim 51$.

Salomom, G. and Cohen, A. A. (1977) Television formate mastery of mental skills, and the aquisition of knowledge. Journal of Educational psychology. 69, (5) pp. 612-619.

Salomon, G. (1979) Media and symbol system as related to cognition and learning. Journal of Educational Psychology. 71, (2)pp. 131-148.

Sceiford, M. (1978) Television for learning. - Further research appotunities. Educational Communication and Technology. 26, (1)pp. 55-63.

Schramm, W. (1977) Some notes on research theory and production in instructional television. Public Tele-communication Review. 5, (4) pp. 11-21.

Szabo, M. Duyer, F. M. and DeMebo, H. (1981) ,Visual testing — Visual literacy's second dimension. Educational Communication and Technology. 29, (3) pp. 177-187.

多田俊文，他（1966）子どもの思考力からみた番組のあり方に関する実験研究 NHK 文呼年報，11集 p. $15 \sim 46$.

多田俊交, 他 (1980) イメージ化と映像教材の学習に関関する実験的研究 日本放送教育学会編, 放送教 育研究, 10 号 p. 21 66.

高知尾 徳（1978）戦前・戦後の放送教育 〜教師の立場から〜 教育と放送を考兄る会編, 放送教育証 言集

高桑康雄（1978）放送教育の復興と発展 教育と放送考考元る会編，放送教育の新展開 p. 58 .

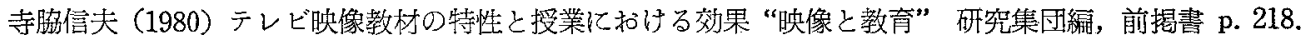

浦 達也（1981）学校放送のハードとソフト 一新しい放送教育諭への試み一 放送教育 8 月号 p. 28.

Vester, F. (1975) Denken, Lernen, Vergessen. (Deutsche Verlags-Anstalt.)

吉崎静夫 (1981) 視聴能力と発展学習の個人差の分析 水越敏行編 視聴能力の形成と評価 所収 pp. 89 $\sim 104$. 


\section{EDUCATIONAL BROADCASTING IN JAPAN}

- Its Retrospect and Prospect —

\section{SUMMARY}

1. Japanese educational broadcasting is about 50 years old for the radio and about 30 years old for the TV. From the beginning, "educational broadcasting" was synonimous with "school broadcating". Nowadays about $90 \%$ of kindergartens and elementary schools, $55 \%$ of junior and senior high schools are considered to be utilizing the broadcasts. However, the history of 50 years was not a smooth one: It has been a very exciting and eventful journey, as it were. This journey may be divided into four laps: they are (1) Radio period (2) TV period (3) VTR period (4) New Media period.

New hardwares appered one after another. Also, the processes of the older media were always limited in their repertoire. Radio, an older media, for example, has been coexisting with the new media (e. g. TV)-limited, though-emphasizing its strong points. 2. Considerable results have been obtained in the diffusion of educational/school broadcasting and, now, there are many problems. Japanese school broadcasting has been increased on the promise that the teachers adopt $\mathrm{TV}$ and/or radio programs and that they correspond with their students. As a result, many characteristics that are incidental to on-air broadcasting have been underestimated. With the coming of the "New Media", era, the diversification and specialization of TV information may be increased rapidly. Therefore, future educational broadcasting must be re-examined from the "educational journalism" point of view.

3. We must seek after the educational/school broadcasting not only for the sake of the campaign, but also for the sake of new academic objects of the interdiciplinary studies. What should be the main theme of audio-visual education in the near future? The following points can be enumerated.

1. The basic study of the iconic, non-verbal communication and learning.

2. The study on the mechanism/structure of the audio visual literacy and its individual differences.

3. The development of the evaluational tools and methods of evaluation of audiovisual literacy, using the iconic codes.

4. Grouping TV and/or radio lessons into four or five types and analizing the teaching-learning strategies of each type.

\section{PREFACE}

School programs have been taking the leading part in Japanese educational broad- 
casting since its very beginning and it's still so. It has been 50 years since nationwide radio broadcastig for schools began in 1935 and 30 years since TV broadcasting for schools started in 1953. Now there is every kind of school broadcasting program intended for children of every age-from kindergartens to senior high schools.

They have increased so much as to fill the radio and TV time tables. The number of schools utilizing school broadcasts rapidly increased to be about $90 \%$ kindergartens, 95\% of primary schools, and 55\% of junior and senior high schools. (However, we must take into consideration that even if there is no more than one class that utilized the broadcasts, it is counted as "school utilizing broadcasting").

At the 1st Grand Meeting of All Japan Teachers Federation of Educational Broadcasting Research Association held in Tokyo 1950, approximately 1300 teachers gathered for two days. At the 14th meeting in Shizuoka 1963, the number of teachers increased to 17,000. The Japanses archipelago is divided into 8 blocks for this association, and every year one block out of them takes charge of the Grand Meeting in turns.

More than 10,000 teachers are participating in it. This shows that the reserch on educational broadcasting has gained broad and steady foundation.

To understand Educational Broadcasting in Japan, some reference to the Japanese Education system may be necessary. An important characteric of education in Japan is that the percentage of school attendance in the 9-year compulsory primary and junior high and the 3-year non compulsory senior high school, are both very high. In $1977,99.9 \%$ of the population reaching school age attended primary school; and 95\% of junior high graduates attend senior high school. Another important characteristic of Japanese education is that Japanese teachers are licenced; and go into the teaching profession after a severe examination. Uuder such a situation, the wonder is why school broadcasting has become so popular as an educational medium besides teachers and textbooks.

Meanwhile, we can see a remarkable progress in the production of hardware... for instance, monochrome telecast swiched over to color, VHF, UHF and sound multiple broadcasting; and still more, VTR have become available. The VTR itself is getting more compact ; the cassette type replaced the open type ; internal timer is now indispensible for pre-set recordings. All these changed the characteristics of broadcasting: that is, broadcasting has lost its principle of momentaryness; audience can use their favourite programs at any time they like. In addition, new media which do not need antena have appeared. The pictures on TV are not necessarily reflecting the "electric wave through air". Moreover, the appearance of cable TV has now enabled the mutual communication between the programmers and viewers.

The progress in the manufacture of hardware is accompanied by changes in the software, too. These are the changes toward diversification and specialization. Now, this is the era in which various kinds of specialized program aimed at specific people 
are broadcast and the audience utilize only that part which is necessary to them. According to Shunichi Itatani, the name broadcasting (which means the spontaneous telecast covering broad area) must be altered to "narrow-casting". (Itatani,S. 1982)

The essential changes mentioned above are very revolutionary ones which are brought about by electronics technology. Educational broadcasting in Japan has passed through the first era of radio, the second era of TV, and the third era of VTR. Now, the fourth era of New Media is near at hand.

This article contains three parts. Part I deals with the 50 years of eventful history of educational broadcasting. The principal objective of this part is to manifest the characteristics of each of the four eras, both from the maker's and the user's points of view. Part II deals with several problems which appeared after the qualitative and quantitative enrichment and expansion of Japanese educational broadcasting. Part III deals with the suggestions as regards the direction that educational broadcasting should be taking and highlights the problems that need solving with the help of research. 